\title{
Diseases Spread by Sea: Health services and the ports of the Canary Islands in the eighteenth and early nineteenth centuries
}

\section{Juan Manuel Santana-Pérez}

To cite this article: Juan Manuel Santana-Pérez (2016) Diseases Spread by Sea: Health services and the ports of the Canary Islands in the eighteenth and early nineteenth centuries, The Mariner's Mirror, 102:3, 290-302, DOI: 10.1080/00253359.2016.1202483

To link to this article: https://doi.org/10.1080/00253359.2016.1202483

曲 Published online: 19 Jul 2016.

Submit your article to this journal $\pi$

Џ Article views: 125

View Crossmark data $\sqsubset$ 


\title{
Diseases Spread by Sea: Health services and the ports of the Canary Islands in the eighteenth and early nineteenth centuries
}

\author{
Juan Manuel Santana-Pérez
}

In the Canary Islands the sea was as a defence against disease. There was a constant fear of epidemics arriving by sea, not only because of the potentially high death toll, but because it could have a seriously detrimental effect on trade. As well as the local impact of disease, health control was important because the Canary Islands acted as an important buffer zone in the control of infection in the Spanish-American trade. Central and local administrations were created to manage health and to control the risk of disease entering the ports and to prevent epidemics from spreading to the interior of the islands. All arriving ships were inspected and any suspicious vessels were quarantined to contain any contagion. Specific quarantine areas were designated and these were developed with facilities such as infirmaries for the sick. Despite these measures the administrative control was weak and epidemics spread through the islands on a number of occasions throughout the eighteenth and nineteenth centuries.

Key words: ports, Board of Health, quarantine, epidemics, Canary Islands, smallpox, yellow fever, scurvy, infection control

$I^{\prime}$

$\mathrm{n}$ the Canary Islands the sea was used to maintain a system of defence against external threats from both people and disease. ${ }^{.}$Diseases brought in by sea, once established on the islands, could spread with great virulence and on a number of occasions had devastating consequences for the local population. ${ }^{2}$ There was therefore a constant fear of epidemics arriving by sea, not only because of the high death toll, but because it could have a seriously detrimental effect on trade through ports being declared 'dirty'. The plague was the most contagious disease, but smallpox had the worst demographic impact and was therefore the primary concern of the state and its health services. ${ }^{3}$ Other diseases such as yellow fever and malaria (named tertian fevers) were also of great concern and scurvy was also thought to be contagious.

As well as the local impact of disease, the Canary Islands, due to their location, acted as an important buffer zone in the control of infection in the Spanish-American trade in a similar way that Malta provided infection control between the eastern and western Mediterranean. ${ }^{4}$ A great deal of physical and administrative effort was

\footnotetext{
I Martínez Shaw has analysed of the urban characteristics acquired by port cities during the ancien regime, including defence elements designed to protect against possible attacks and institutional infrastructures tasked with preventing the arrival of epidemics. Martínez-Shaw, 'La ciudad y el mar', 270.

2 Bethencourt Massieu, 'Inoculación y vacuna'.

3 Nadal, La población española.

4 Vassallo, Corsairing to Commerce, I I 5-I7 and 97-9.
} 
therefore put into maintaining control measures such as the inspection of all ships and the quarantine of any that were considered suspicious.

\section{Health administration}

In the Canary Islands the commandant general was the supreme authority, and had responsibility for all health matters. Each island also possessed a single municipal regime known as a cabildo, with island-wide authority to defend the interests of its populace. During the eighteenth century these local administrations were tasked with preventing the entry of disease through the seaports and had a dedicated budget specifically for this purpose, demonstrating the great significance of this issue. On the islands of Gran Canaria, Tenerife and La Palma they were presided over by a chief magistrate while the islands of Fuerteventura, Lanzarote, Gomera and El Hierro had mayors or deputy mayors.

The national government also took measures to secure the health of the Spanish population as a whole.' In I7 I7 José Patiño, Philip V's prime minister, enacted the first maritime health law, with the aim of securing patient care and hygiene control aboard ships. On 2 October 1720 Philip V also created an administrative judicial body, the Supreme Board of Health, which was confirmed by royal decree on ro October I72I. It was initially created to prevent the plague that was at the time spreading along the French Mediterranean coast. The board was mainly composed of lawyers and was active until I 847, apart from a brief period between I 805 and I 809 when public health came under the purview of the Ministry of War. ${ }^{6}$ Operating under the control of the Supreme Board of Health was a series of local committees, with health boards established in all the major seaports. In I72I a local Supreme Board of Health was therefore established in the Canaries.

The most important responsibility of the Board of Health in the Canaries was to oversee disease control in all of the island ports and to prevent outbreaks from spreading inland. It sought to rationalize the legislative system in this area through collective rules and powers that would pool the existing provisions, which were almost all dedicated to maritime prevention. These included powers to oversee the arrival and departure of all ships, coastal surveillance and the issuing of prohibitions and commercial permits. ${ }^{7}$

Preventative measures were taken to target both the legal and contraband maritime traffic between the archipelago and overseas ports. The Canary Islands were a regular stopover for vessels employed in the transatlantic trade and the health authorities were therefore particularly concerned with contagious diseases that might be carried from the Americas. ${ }^{8}$

Health controls were often contained in royal decrees which communicated the existence of a disease and detailed how rigorously port movements should be controlled. For example, a royal decree of 1674 informed the registrar judge of

5 Rodríguez Ocaña, 'El resguardo de la salud', I $45-70$.

6 The distressing health situation the authorities faced caused them to reinstate the original body in I 809 . This new board was exclusively dedicated to health-related issues.

7 Varela Peris, 'El papel de la Junta Suprema de Sanidad', 3 i 5-40.

8 Guimerá Ravina, 'Puertos y ciudades portuarias', 298-30I. 
Tenerife that to minimize the possibility of any disease entering its ports 'ships that come from the Indies as well as other ships must be visited'.?

\section{Ship inspections}

As soon as a vessel arrived off the coast of the Canaries, action was taken to direct it to one of the parts that had the adequate infrastructure for a thorough inspection. In these ports a body was established that was charged with inspecting the vessels' state of health, which became known at the end of the eighteenth century as the Health Council. Their health inspections were conducted along the same lines as the Inquisition:

visit all the vessels that come to trade at our ports ... the officials and passengers brought by the Cape will be checked, the scribe and doctor who will come and approach the embarkation or vessel, without entering, will make the captain or patron put all the people up to the railing, under penalty of life sentence if he hides any, as well as the parts they may have entered or touched, and arranged this way they will count them and check their faces to see if any of them is sick. ${ }^{10}$

These regulations were designed to prevent the entry of persons or goods affected by disease. The port authorities were therefore careful not to allow any ship to disembark without first undergoing a meticulous inspection. A royal decree of $\mathrm{i} 674$ stipulated that the chief magistrate of Tenerife, his lieutenant, two deputy councillors and doctors should visit all ships dropping anchor in Tenerife's ports. Where there was proof, or even suspicion, that a vessel was harbouring disease or came from a port known to have an epidemic, specific procedures were applied. First, all vessels were to be detained until the doctors could make an assessment. If the vessel was ordered not to disembark in port any contact between the vessel and the outside world was prohibited. It then had to proceed downwind from the port to minimize any risk of contagion. Once a vessel was quarantined the inspectors would call on the captain to identify all people and cargo on board, and the course taken during the voyage. He was then questioned about the existence of sick people on board and whether they had come from an infected port. ${ }^{\text {II }}$

All ships that arrived in Canarian ports were required to present certification from their port of departure that they did not carry any contagious diseases. ${ }^{12}$ These bills of health were used in most European ports as a means of preventing the import of infection. For example, the Fly of Liverpool, which docked with I4 men in Santa Cruz de Tenerife in I793, presented a certificate from the customs agency of Cork (written in English and Latin) declaring that the boat had no 'outbreak of plague', which generally referred to any contagious disease. ${ }^{13}$ Bills of health were issued by the port authorities in European ports or by European consuls in Muslim countries and certified vessels as clean, suspicious or dirty. ${ }^{14}$

9 Archivo Municipal de La Laguna (hereafter AMLL), Sig. R-XIV, bundle 25, I674, no fo.

Io AMLL, Second Section, Sig. S-III, bundle I 2, I 763 , fo. I 9

I I Ibid.

I 2 AMLL, Second Section, Sig. S-I, I720, no fo.

I3 Archivo Histórico Provincial de Santa Cruz de Tenerife (hereafter AHPS/CTFE), Sig: 2-I 22, Papeles Sueltos de La Orotava, no fo.

I4 Cortés Verdaguer, 'Notas sobre la sanidad marítima mallorquina', i63-70. 
Although there are no known examples of eighteenth-century ships' bills of health in existence, largely because the document would stay with the ship, it is possible to infer the content of these documents. They were written forms indicating that the passengers and merchandise were all in good health, or detailing any specific illnesses known to be present. Not having a certificate was in itself sufficient reason to place a ship in quarantine and impede its disembarkation until an investigation determined the nature of any disease.

In the captain's log from the French vessel El Héctor, which was quarantined at the port of Santa Cruz de Tenerife on 3 March I747, the authorities confirmed that it did not have a health certificate because it had come from America, where many ports did not have this system. After the first consultation with the ship's crew, those responsible for public health met and concluded that the inspection had been insufficient to determine if those aboard were diseased. Therefore the captain, several crew members and passengers were made to disembark and were taken to a distant location known as San Juan. Each was asked the same questions, and once the interview was finished, they went back on board and their declarations were communicated to the chief magistrate. The Board of Health then met the chief magistrate, the general captain and the medical surgeons to determine what measures were to be taken.' ${ }^{\text {Is }}$

The most-cited illnesses that people suffered from were scurvy, yellow fever (also known as black vomit) and smallpox. All of these diseases had a high death rate. In the eighteenth century it was believed that scurvy was caused by ingesting bad and salty foods and was thought to be spread by eating, drinking and sleeping with infected people. However, one of the El Héctor passengers declared that 'scurvy is caused by bad food and all the people who eat well don't have anything' and that this illness was neither dangerous nor contagious. ${ }^{16}$

Black vomit appeared in the questions posed to the captain of the ship Aguas Lluvias, which arrived from Havana on 2I January 1762. The captain, Manuel Capelo Saviñón, responded that:

in Havana it is normal that every year, some more than others, one suffers from black or brown vomit in the months of July and August, due to the great heat, and this disease stops in September. ${ }^{17}$

In the summer of 176I this ship had been docked at Havana. The crew explained that in June they had reached the Cuban capital in a Spanish naval squadron of six ships. Many of the soldiers suffered the disease, which had lasted until September, killing approximately I,900 people, primarily military personnel. A passenger on the ship, Fernando Álvarez, a resident of Icod de los Vinos, also mentioned an outbreak of smallpox: 'the illness unleashed in Havana, afflicting the Spanish military, was black vomit, and later they also got smallpox'. ${ }^{18}$

The majority of the files make no mention of merchandise, however the Aguas Lluvias provides some information about the procedures for inspecting cargo. The ship was carrying a cargo primarily of leather. When the captain and the other individuals were questioned they declared that they had picked up the cargo after

is AMLL, Sig. S-III, bundle 7, I747, no fo.

I6 Ibid.

I7 AMLL, Sig. S-III, bundle Io, I762, no fo.

I 8 Ibid. 
the black vomit epidemic. They said it was well treated, and the hides were in brine, so they cannot cause any infection or pose any danger'. ${ }^{19}$ These claims were corroborated by the similarity of the other responses from those questioned. The doctor in charge of the inspection therefore authorized the unloading of the leather and other cargo but stated that if any hide was in bad condition due to humidity or any other corruption, it should be dried out in a location determined by the Board of Health.

One of the Board of Health's most demanding tasks was to prevent the introduction of disease in food products, which could potentially spread disease further and quicker than infected crew or passengers. Special care was therefore taken to inspect food products:

Anything that could be corrupted is sought out, for which meticulous and repeated inspections are carried out, especially for sardines and herring and other salted edibles, as well as wheat, flour and barley that come by sea - if they are wet or have a bad odour they are not received or they are burned. All captains of boats that fish along the coast are prevented, while these restrictions remain, from bringing plain bonitos (tazartes), aujobajos or kingfish; and fishermen on land who fish in freshwater should not catch nor sell mackerel, kingfish, plain bonitos, and these shall be thrown back into the sea. ${ }^{20}$

Fish was one of the food products most feared by the governors because it could spoil quickly. Authorities were also especially strict about the flour used to make gofio, a typical food of the Canary Islands, establishing the need to carefully inspect imported flour to detect any dampness and to prevent the sale of flour found to be unsatisfactory. ${ }^{21}$

The importance placed on protecting the islands from infectious diseases carried by imported food or arriving travellers can be seen in the 30 letters from the commander general of the province to the council of Lanzarote between 1784 and I 787 in relation to preventing epidemics from being brought into port. ${ }^{22}$

There were often disputes between the chief magistrate and the registrar judge of the Indies caused by uncertainty surrounding the limits of the powers of each role, largely because both, or at least their deputies, were required to visit all ships. The chief magistrate claimed that the remit of registrar judge of the Indies lay only with the cargo and that it was the judge who carried out the health visits. This dispute led Charles II to issue a royal decree in a I674, motivated by a letter from the chief magistrate, to limit the jurisdiction of each:

We want and We order that now and henceforth the Judge and Brigade of this Island shall conduct the health visit to the ships as has been done and executed in the form until now, and also that you, Mr Diego Salazar y Trillo, registrar judge of the Indies in the island of Tenerife, will not intervene in this health visit, nor impede that which the said Judge and Brigade do in the form referenced. ${ }^{23}$

i9 AMLL, Sig. S-III, bundle Io, I762, no fo.

20 AMLL, Section Second, Sig. S-I, bundle 2, I720-85, fo. 7.

2 I AMLL, Second Section, Sig. S-I, bundle I, fo. 62

22 Rodríguez Arrocha, 'Correspondencia entre el marqués'.

23 AMLL, Sig. R-XIV, bundle 25, I674, no fo. 
The decree also indicated that the registrar judge of the Indies should refrain from making visits, but only register the cargo of the ships coming from America which fell under the administration of the Casa de Contratación in Seville, but excluding any ships coming from Brazil, Cape Verde and Guinea. ${ }^{24}$

In one report several ships arrived at the port of Santa Cruz de Tenerife and were visited by the health lieutenant between 3i December 1787 and 3i December I788. The account details the monetary expenditures for each ship visit, even noting the number of visits made to each embarkation and the number of people who participated. It gives the name of the boat, the number of crew and passengers, port of departure and destination and, finally, how many days they had been travelling.

The ship owners themselves had to cover the costs of the ship inspections and any period of quarantine. In Lanzarote each arriving vessel was required to pay I 3 reales vellon, which was to be distributed as follows: 4 for the soldier carrying the information to the Board of Health, 4 for the Board, I to the Castillo officer acting as harbourmaster and 4 for the 'Commander de Arms'. ${ }^{25}$ For the local authorities these fees could become more important that the prevention of disease. For example, in I 8 I 0 a note of health was issued for the Canary fishing boats bound for the Saharan fishing banks. These could be purchased for 500 pesos, as long as no fisherman had died on board and there was no sickness. ${ }^{26}$ The owners of fishing vessels in Africa also complained that the master of every new arrival at the port of Santa Cruz was required to pay seven pesos under the pretext of a health visit. ${ }^{27}$ In an attempt to avoid abuses, though, heavy formalities were specified to mire the inspecting authorities in bureaucracy. ${ }^{28}$

\section{Quarantine areas}

When there was a risk of outside contagion, the first health measure was to close the island's ports and jetties. The owners of the boats and the personnel in charge of the quays were strictly forbidden to allow any unwanted disembarkations. One of the most common measures used to combat the threat of infected vessels was to place them in quarantine, but other more drastic actions could also take place. From a letter received by the Marquis of Villanueva del Prado, we learn that the San Miguel was burned at the port of Santa Cruz de Tenerife on suspicion of being infected. ${ }^{29}$

A great deal of care was taken to prevent vessels from landing at non-designated ports. Santa Cruz and La Orotava explicitly refused landings in Adeje, Garachico and other ports in order to maintain health control. ${ }^{30}$ However, there was also unregulated illicit maritime traffic along the most vulnerable coastlines which was

24 The Casa de Contratación was the government agency charged with the exploration, colonization and trade with the Spanish colonies.

25 Rodríguez Arrocha, 'Correspondencia entre el marqués'. Some charges at Canary ports by the Board of Health for inspection visits can be found in ABMS/CTFE, Caja 25, Navegación y Puertos $3^{\circ}$ Sanidad, s/fol.

26 Romero Y Ceballos, Diario cronológico histórico, vol. 2, I79.

27 AMLL Sig: P-XXXI, bundle i I, I770, fo. 2.

28 Cortés Verdaguer, 'La prevención sanitaria en Mallorca'.

29 Archivo de la Real Sociedad Económica de Amigos del País de Tenerife (hereafter ARSEAPTFE) Fondo Rodríguez Moure, Sig: 20/6, bundle I, fo. 96 r.

30 AMLL, Second Section, Sig. S-I, bundle I, I $720-85$, fo. 7 
less easy to control. In 1746 the concerns of Canarian authorities were made evident when two foreign ships were reported to have arrived at the jetties of Caleta de Fuste and Las Playas, and their crew went ashore and stocked up on water, firewood and other goods without the necessary control procedures being enacted. As a result the deputy mayor was reprimanded and instructed not to let this happen again. ${ }^{31}$

The health authorities were particularly vigilant in keeping up to date with news about the development of epidemics in Europe. When an outbreak was reported, trade relations were prohibited and boats arriving in the Canaries from the affected area were prevented from disembarking people or goods and were quarantined:

none of the ports of this kingdom will allow any disembarkation great or small coming from Algiers, Smyrna, Alexandria and the Islands of the Archipelago where contagion has been introduced; rather they will immediately be made to leave, obliged by force if they resist, because one of the embarkations could approach the beaches, coves and inlets and other places to anchor along our coasts ... these important restrictions should be enforced in the respective jurisdictions to prohibit embarkations from entering or approaching land ... likewise any ship that ejects or disembarks people, fruits, merchandise, or any other kind under any circumstances make them return to the open sea, firing upon them if necessary. ${ }^{32}$

The general commander of the Board of Health in Cadiz sent a dispatch to the council of Fuerteventura prohibiting any person from coming into contact with foreign vessels before the mayor's health inspection had given the all clear. The same inspection regime applied to fishing boats and vessels engaged in inter-island trade. If any foreigners were landed they were to be stopped and isolated by the Supreme Board of Health..$^{33}$ A system of coastal monitoring was also established, which prohibited the island's inhabitants from making illicit contact with foreign vessels, under penalty of death.

In I742, during a period marked by plague epidemics in Marseilles and Algiers, the king was informed of the serious impact on Canarian trade of the Board of Health's strict anchoring and registering of vessels. The king resolved to end the rigidity of the Board's operations and added:

in recognition of the Dispatches under which the Captains and Patrons sail, and if shown by them not to have come from nor have touched in their voyage the site where this illness is suffered, the license to trade shall be given promptly without excessive expense or delay and without subjecting them to anchor and registry ... quarantine without unloading nor giving admission to others who may come during this communication. ${ }^{34}$

In 1776 a suspicious ship arrived at the port of Santa Cruz de Tenerife that was suspected of carrying smallpox. Due to this suspicion, the ship was transferred to a specific location called the Rada del Degredo, where it was quarantined and the

3I Archivo del Cabildo de Fuerteventura (hereafter ACF), bundle 4-a, minutes 6 March I746, fo. 26.

32 AMLL, Sig. S-III, bundle I2, I763, fo. I7

33 ACF, bundle 4-a, minutes August I, I759, fo. I 43.

34 British Library (hereafter BL), Add. MS 20926, fos 39-40. 
necessary measures taken to contain the disease and prevent its spread. ${ }^{35}$

The most infamous plague epidemic of the eighteenth century was the Dalmatian plague of 1784 . When the islands' authorities became aware of it they worked quickly to implement strict and rigorous isolation measures for boats coming from that region. During this epidemic the local fishing boats were required to bring an identification flag to enter the island ports..$^{36}$

In the records of the council of Tenerife, there are three files referring to yellow fever, indicating that this disease came from different locations on the American continent. Two council documents report that an epidemic of yellow fever had broken out in Philadelphia and that vessels coming from this port should be quarantined. They called the disease 'yellow temperature', describing it as a terrible 'plague' that had attacked Philadelphia and New York extensively. After this epidemic disappeared, documents were sent to lift the quarantine in the Canarian ports, although extreme vigilance was still to be maintained. ${ }^{37}$ An order from 1799 also warned about a yellow fever epidemic in Philadelphia, ${ }^{38}$ and a letter from the Council notified the authorities of another epidemic in the colonies of Santa Cruz and Santo Tomás, which required the implementation of quarantine for all vessels coming from those ports. ${ }^{39}$

In 1787 the Marquis de Branciforte wrote two letters to the Cabildo of Fuerteventura in which he relates that the king had established quarantine regulations for all Russian, Swedish and Danish ships, for fear of the possible spread of epidemics..$^{\circ}$ Later, in March I 802, another commander general of the province sent several letters to the council of Fuerteventura to apply control measures, with a penalty of ro० ducados for any vessel failing to comply. ${ }^{4}$

As well as the regulations concerning the landing of foreign vessels, there was also a prohibition against captains or owners of native boats from leaving port to board vessels that were sighted at sea, and they were forbidden from landing any merchandise, fruits or passengers taken from these ships. Violations were punished with fines of 200 pesos, which was spent on the costs of war or fortification. Those who could not pay received 200 lashes.

\section{Quarantine infirmaries}

Quarantine infirmaries were developed in the eighteenth century. These were spacious, fenced-in buildings located near to the sea. They were built to receive goods and people when quarantine was imposed on ships. European ports that had more contact with the coast of North Africa were the first to set up these spaces. In I 403 the first infirmary was established on an island near Venice. They also appeared in Marseilles, Genoa and other ports of the Italian peninsula and this example spread throughout Europe..$^{22}$ As well as containing any infection they also had the advantage of generating confidence in ships sailing from these ports.

35 AMLL, Second Section, Sig. S-III, bundle $17, \mathrm{I776}$, fos I-3.

36 Romero Y Ceballos, Diario cronológico histórico, vol. I, I 20.

37 AMLL Sig. S-IV, bundle 42, I799 and S-IV, bundle 43, I799.

38 AMLL, Sig. S-IV, bundle 42, I799, no fo. and S-IV, bundle 43, I799, no fo.

39 AMLL, Sig. S-IV, bundle 44, I799, no fo.

40 ACF, bundle 9-a, minutes I March, i787, fo. 4I.

4I Cerdeña Ruiz, Acuerdos del Cabildo de Fuerteventura, I9I-2.

42 Panzac, Quarantines et Lazarets. 
From its inception, the Supreme Board of Health supervised the infirmaries and established guidelines for the construction of new ones in accordance with provincial and local boards of health. The first modern infirmary in Spain, built along the lines of these European models, was established in Minorca in the port of Mahon. It was first projected in 1787 , but construction was only begun in September 1793, prompted by the plague that hit Algeria that year. In I 798 building work was halted when the island returned temporarily to English hands, but was resumed in I 803 and it came fully into service from July i 8 I 7 , from which date it became Spain's most important infirmary.43

Having a quarantine infirmary for passengers and goods became a serious concern for the health authorities on the Canary Islands and the construction of quarantine facilities became one of their most repeated directives. A provisional infirmary was set up in Tenerife, and in La Palma the authorities demanded the construction of a quarantine facility to hold arriving passengers and crew suffering from plagues or contagious diseases. ${ }^{44}$

Convinced that constructing quarantine facilities was the most effective way to prevent contagion in the general population, the health authorities established guidelines for their construction. These were in the form of a general decree handed down by the Spanish Crown. The quarantine facilities were ideally located far from any town, with the minimum distance 'three gunshots [away], and even then on the lee side of the country's winds'. They were required to be well ventilated, with many windows and doors. However, these openings were to remain closed on the side of the building facing the homes of the islanders to prevent winds carrying contagion from inside the facility to the local inhabitants. Nevertheless, they were to be opened often to circulate the air and purify the environment. It was therefore best for quarantine facilities to be located along the sea or near a ravine whose waters could be used to maintain the cleanliness of the patients.

To combat disease, bonfires and the burning of herbs and aromatic plants were used to clean the atmosphere. The nearby towns also lit bonfires daily 'because it is verified that fire is one of the best known correctives'.45 The servants washed themselves with infusions of vinegar, and a hot version of this cleanser was sprayed on the ceilings, floors, and walls of the facility. These were the best-known measures for fighting disease at the time.

The authorities advised those in quarantine to change their clothing every few days because cleanliness was an important precaution against contagion. It was also necessary for each quarantine facility to have a common room, situated such that the vapours of the sick would not enter the bedrooms. Similarly, bedpans, spittoons, and urinals were not allowed into bedrooms and if their use was necessary during the night, they were washed in the morning. When a quarantined inmate fell ill in the facility, he or she would be removed without delay from the common rooms and put into a solitary cell to be treated.

Those who worked at the facility, such as doctors and priests, were required to be clothed in silk, avoiding wool and cotton. The bleeders and servants could wear

43 Rodríguez, Lazareto de Maón; López Nadal, 'La sanidad marítima'.

44 Archivo Municipal de Santa Cruz de La Palma (hereafter AMS/CLP) Sanidad, Sig.

I7-308-Unica, I785, fo. I

45 AMLL, Second Section, Sig. S-I, bundle I, I784, no fo.. 
linen or canvas, but they were prohibited from eating at the table or use the plates of those under quarantine, nor could they wash themselves in their sinks or sleep in their quarters.

Those under quarantine ate good bread daily, and the preferred meat included chicken, mutton and beef. Pork and all salted or smoked meat was considered less safe. The indigenous vegetables of the Canaries did not appear to be noxious and could be safely included on the menu.

The majority of ships coming into the Canary Islands had at least one ill passenger. Bad weather, rotting food and the scarcity of food made passengers vulnerable to infection. For example, numerous sick people arrived at Tenerife on an American frigate on I4 November $178 \mathrm{I}$. After quarantine the sick were transferred to hospital to be examined and to determine how many were afflicted. Dr Miguel de los Santos observed that there were I07 sick, diagnosing most with various illnesses he categorized as 'intermittent fevers'. Others had catarrhal fevers and chest-, nose-, and scurvy-related problems. Nevertheless, he reported that there was no threat of epidemic, though he ordered that no one was to board the ship and that the frigate should be stationed downwind. He allowed the less sick patients in the hospital to be transferred to private houses, so long as these were downwind to prevent them from infecting other inmates. He also indicated that the isolated patients should not return to the ship until they were robust and completely healthy. ${ }^{46}$

\section{Controlling the spread of epidemics}

Although all foreign diseases were dangerous, the authorities placed special emphasis on preventing the introduction of the plague, which had claimed the most lives in previous centuries. From the sixteenth century it became common to pray to patron saints, as occurred in La Laguna, the capital of the archipelago in I 582 when the plague was ravaging the city. Saint John the Baptist reputedly intervened which coincided with the end of contagion, so a chapel was erected in his honour. ${ }^{47}$

However, more temporal means of stopping the spread of disease were also needed, although these were more costly. Due to a lack of funds, it was difficult for local administrations to comply with all the guidelines relating to quarantine. In fact it was rare for them to manage disease outbreaks successfully as the majority of the provisions ordered by the health authorities were simply undermined by those tasked with applying them. Epidemics therefore spread with some frequency:

The Supreme Board of Health has had news by authorized channels of much carelessness with which some of the ports of this peninsula are keeping quarantine, ... the lack of regular precautions in the use of vinegar and the practice of receiving letters and money from the crews, has reached the point where it has been noted that for personal reasons some of the individuals from the same ships that were under ongoing quarantine have been allowed to jump to the land..$^{8}$

Once an outbreak did occur in port, the local administrations were also responsible for preventing the disease from spreading to the rest of the island. When

46 AMLL, Sig. S-IV, bundle I, I78 I, no fo.

47 ARSEAPTFE, Fondo Rodríguez Moure, Sig: 22/36, bundle 230, fo. I 2 r.

48 AMLL, Second Section, Sig. S-I, bundle I, I786, no fo.. 
this happened the authorities tried to prevent the residents of the affected area from coming into contact with healthy people. This measure was somewhat effective on the islands whose terrain was marked by isolated ravines as it was easy to close off a geographic area in such terrain. One such case occurred in I8 10 in Santa Cruz de Tenerife when the inter-island council of the Canary Islands took the necessary precautions. Isolation was the primary solution adopted, a strict barrier was erected to keep the city isolated from other other towns and temporary quarantine quarters were established:

to prevent communication between the residents of the town of Santa Cruz with this Capital and other towns so as not to extend the contagion or epidemic they are suffering, a house was established to hold suspicious people for a period of time. ${ }^{49}$

This caused supply difficulties for the inhabitants so the commander general of the province called on merchants who usually sold their goods in the city to instead take them to the barrier, where the residents of Santa Cruz could meet them and obtain the necessary food. However, the irregularities of this situation led to problems. There was corruption on the supply side and some merchants tried to make a lucrative business out of the captive market:

with the multitude of people who go up to the barrier, the disorder grows daily and some of them buy things that before reaching here have been resold three times, such that some of these articles carry extremely high prices ... it would be best if you could name six, eight, ten or more people who could cross when they came to the barrier and then take the goods to the town to sell them publicly.90

Another grave problem with the health barrier was the constant attempts made by the inhabitants of Santa Cruz to escape. Because it was impossible to cross the barrier, they risked their lives trying to escape through the ravines and so the authorities placed guards there and in other areas to try to contain the affected population.

Without food and financial assistance from the rest of the archipelago, it was difficult to overcome the epidemic. However, those on other islands did not feel safe in approaching Tenerife as they knew it was infected. The people of Tenerife therefore sought to convince their neighbours that only Santa Cruz was infected. The scarcity of food was a particular problem and an appeal was sent to the rest of the archipelago to help:

this should not hinder you, in light of your usual generosity, to give the appropriate orders to help the beleaguered town of Santa Cruz with provisions whose lack will be sorely felt if the shipments that normally bring them were suspended. ${ }^{\text {sI }}$

Similar circumstances were reported in another area of Tenerife a few years later, when a smallpox outbreak occurred in Puerto de la Cruz in I 827 and the authorities

49 AMLL, Sig. S-I, bundle I I, I 8 I o, fo. I. The Council of Tenerife wrote to the island villages to prevent the spread of disease. ARSEAPTFE Fondo Rodríguez Moure, Sig: 20/6, bundle I33, fo. $248 \mathrm{r}$.

so AMLL, Sig. S-II, bundle 3, I 8 Io, no fo.

s I Ibid. 
halted trade to the port to try and prevent the spread of the disease to other ports on the island. ${ }^{2}$ Despite these controls it was still common for disease to spread beyond the restricted areas.

Occasionally, the islands had to respond to external factors as well, such as the proposed transfer of a battalion of soldiers from the Canaries, which was scheduled to arrive in the archipelago from Andalusia in I 801. ${ }^{33}$ At that time Andalusia was suffering a yellow fever epidemic and this news caused fear in the islands. The town council of La Orotava, whose port was chosen for disembarking the troops, sent multiple letters to the inter-island council of the Canary Islands asking it to prevent the disembarkation until the danger was over. ${ }^{54}$

\section{Conclusions}

Overall, the Spanish measures to maintain port health in the eighteenth century saw no significant changes from the system operating the sixteenth and seventeenth centuries. Constant financial problems sapped the effectiveness of health provision in the Canary Islands. Port security, with the quarantine of vessels, people and goods was therefore the most commonly used precaution. However, the vigilance of the ports in trying to prevent disease could also be counterproductive by making them inoperable, hindering communication and trade and even obstructing the arrival of medicines and official orders.

Despite the control measures based on maritime isolation, the archipelago of the Canaries still experienced repeated smallpox epidemics over the course of the eighteenth century. Santa Cruz de Tenerife was seriously affected in 1709, I720, I73 I, I744 and I759 and Santa Cruz de La Palma in I720 and 1759, although the death tolls tended to be relatively low.

The limitations of the ancien regime with respect to health in the Canary Islands were seriously exposed in $18 \mathrm{I} 0$ when a yellow fever epidemic was declared in the port of Santa Cruz de Tenerife and then quickly spread to Puerto de la Cruz, and from there to La Laguna and then to the whole archipelago.ss Another major outbreak occurred between I 844 and I 852 in the northern municipalities of Gran Canaria, which suffered a serious demographic collapse because of epidemics of yellow fever and Asian cholera. ${ }^{6}$

Measures for improving public health in the Canaries were difficult to implement, especially when the problem was so deeply ingrained in the social structure. Without modifying the quality of life and improving hygiene, it was impossible to eradicate disease in the places where it proliferated.

The Supreme Board of Health was abolished in 1847 as part of a reform of the Spanish state administration and the powers and the resposibilities for health care were transferred to the Ministry of the Interior. However, the deficiencies in epidemic control in the Canary Islands continued well into the twentieth century.

52 Archivo Municipal del Puerto de la Cruz, Beneficencia y Sanidad, bundle 58, No. 8, I827I 828 , fo. I.

53 Aréjula, Breve descripción.

54 AMLL, Sig. S-IV, bundle 48, I80 I, fo. I.

55 BL, Add. MS I 7638 , fos 33-4.

56 Dominguez Mujica and Diaz Hernandez, 'Hambre y epidemias'. 
Juan Manuel Santana-Pérez is Professor of Early Modern History at the Universidad de Las Palmas de Gran Canaria and Professor in the PhD Programme in History and Humanities at the Universidad Pablo de Olavide, Seville. His research interests are in the maritime history of the Atlantic between the sixteenth and eighteenth centuries.

\section{References}

Aréjula, J. M., Breve descripción de la fiebre amarilla padecida en Cádiz y pueblos comarcanos en I 800, en Medinasidonia en I 80 I, en Málaga en I 803 y en esta misma plaza y otras del Reyno (Madrid I 806)

Bethencourt Massieu, A., 'Inoculación y vacuna antivarólica en Canarias i 760-I 830', V Coloquio de Historia Canario-Americana (1982), 2, (Madrid, I986), 279-307

Cerdeña Ruiz, R. (ed.), Acuerdos del Cabildo de Fuerteventura, (1799-1 834) (Puerto del Rosario, 2008)

Cortés Verdaguer, J. M. J., , 'Notas sobre la sanidad marítima mallorquina en el siglo xviII', Bolletí de la Societat Arqueològica Lul.liana, 57, (2001), 163-70

-, La prevención sanitaria en Mallorca durante el siglo XVIII (I7I8-I803), (Madrid, 20I I)

Dominguez Mujica, J. and Diaz Hernandez, R., 'Hambre y epidemias entre I 844-I 852 en el norte de Gran Canaria', V Coloquio de Historia Canario-Americana (1982), 2, (Madrid, I986), 309-80

Guimerá Ravina, A., 'Puertos y ciudades portuarias (Ss. XVI-XVIII): una aproximación metodológica' in I. Amorim, A. Polónia and H. Osswald (eds.), O Litoral em Pespectiva Histórica (Séc. XVI a XVIII), (Porto, 2002), 28 5-305

López Nadal, G., 'La sanidad marítima menorquina anterior al funcionamiento del lazareto de Mahón', in Menorca en la historia de la Sanidad. El Doctor Orfila, toxicología y medicina legal. El lazareto, fundación del rey Carlos III en Menorca (Madrid, I987), 8 I-Io8

Martínez Shaw, C., 'La ciudad y el mar. La ciudad marítima y sus funciones en el Antiguo Régimen', Manuscrits, is (I997), 257-78

Nadal I Oller, J., La población española (siglo XVI a XX) (Barcelona, I976)

Panzac, D. Quarantines et Lazarets. L'Europe et la peste d'Oriente, (Aix-en-Provence, 1986)

Rodríguez, M., Lazareto de Maón ó Memoria descriptiva de sus obras, reflexiones críticas sobre su estado actual y proyecto para que sea general y el puerto franco en beneficio del comercio del Mediterráneo (Mahón, I 8 I 3 )

Rodríguez Arrocha, B., 'Correspondencia entre el marqués de Branciforte, Comandante General de las Islas Canarias, y el cabildo de Lanzarote, relativa a la prevención del contagio de la peste, I784,1787', Revista de Historia de Canarias, I 89 (May 2007), I99-2 I 8

Rodríguez Ocaña, E., 'El resguardo de la salud. Organización sanitaria española en el siglo Xvin', Dynamis, 7-8, (1987-1988), I45-170

Romero Y Ceballos, I., Diario cronológico histórico de los sucesos elementales, políticos e históricos de esta isla de Gran Canaria (I780-I8I4), 2 vols (Las Palmas de Gran Canaria, 2002)

Varela Peris, F., 'El papel de la Junta Suprema de Sanidad en la política sanitaria española del siglo XVIII', Dynamis, I 8 ( I 998), 3 I 5-40

Vassallo, C., Corsairing to Commerce: Maltese merchants in XVIII century Spain, (Malta, I997) 